\title{
Az észlelt kockázat utazási szándékra gyakorolt hatása konfliktusövezetekben: elméleti keretmodell
}

\author{
Szerzők: Bayramov Elimdar ${ }^{1}$ - Agárdi Irma²
}

A politikai instabilitás okozta konfliktusok száma világszerte növekszik, ami negatív hatást gyakorol a turizmusra és növeli az utazással kapcsolatos észlelt kockázatot. A turizmus-szakirodalomban kevés olyan kutatást végeztek, amelyek a konfliktusövezetekben található desztinációkkal kapcsolatos utazási szándék befolyásoló tényezöit vizsgálták. A tanulmány célja, hogy egy olyan elméleti keretmodellt alakítson ki, amely az észlelt kockázat és a turisták látogatási szándékának összefüggését vizsgálja konfliktusövezetekben található desztinációkban. A keretmodellt a tervezett magatartás elméletét alapul véve alakítottuk ki, amely figyelembe veszi az észlelt kockázat és észlelt bizonytalanság hatását az utazási szándékot és tényleges magatartást meghatározó tényezókre: a tényleges magatartásra vonatkozó attitüdökre, a szubjektív normákra és az észlelt magatartásirányitásra. Ú elemként jelenik meg a modellben, hogy a desztinációval kapcsolatos korábbi tapasztalat és a desztinációimázs szintén befolyásolja az utazási szándékot. Az elméleti keretmodell egy jövóbeni empirikus kutatás kiindulópontja.

Kulcsszavak: konfliktusövezet, észlelt kockázat, utazási szándék.

\section{Bevezetés}

A turizmus szektor folyamatosan növekszik, nemzetközi szinten a turisztikai célú látogatások (legalább 1 éjszaka) 2015-ben 4,6 százalékkal növekedtek és globális szinten elérték az 1186 millió fót, ami 52 millióval több, mint az előző évben (UNWTO 2016). A turizmus világszerte vezetó iparágnak számít, mivel a globális GDP-hez 7,2 trillió dollárral járult hozzá, ami a teljes GDP 9,8 százalékát teszi ki (WTTC 2017).

A globális turizmusra hatással vannak a külső környezet eseményei és válságai, ezért a negatív események jelentősen megváltoztathatják az utazási magatartást (MICHALKÓ 2012). A turizmusra negatív hatást gyakorolnak a természeti katasztrófák, a háborúk, a politikai instabilitás és a terrorizmus, ami nem csupán a keresletet, hanem a turizmus irányát is befolyásolja (SÖNMEZ 1998). Franciaországban például több terrortámadás történt 2015-ben, amelynek hatására a turizmus GDP-hez való hozzájárulása 7,1 milliárd dollárral csökkent. A világ különböző részein tapasztalható, növekvő számú konfliktus (például politikai instabilitás, háború és terrorizmus) miatt a turisták

\footnotetext{
1 PhD-hallgató, Budapesti Corvinus Egyetem, elimdar@gmail.com 2 egyetemi docens, Budapesti Corvinus Egyetem, irma.agardi@uni-corvinus.hu
}

nagyobb figyelmet szentelnek az utazással kapcsolatos kockázatoknak. A magas észlelt kockázat viszont az utazás egyik legfontosabb akadályává válhat (UM et al. 2006, LARSEN et al. 2007).

A turizmusban intenzíven kutatták az észlelt kockázatot a kilencvenes években, melynek során kimutatták, hogy az utazók igyekeznek elkerülni azokat a desztinációkat, amelyek esetében magas kockázatot észlelnek (ROEHL - FESENMAIER 1992, SÖNMEZ - GRAEFE 1998a, 1998b). Későbbi kutatások (LEPP - GIBSON 2003) azonban megállapították, hogy az utazók eltéróen ítélik meg a nemzetközi utazásokkal együtt járó kockázatokat. Az objektív kockázat és a turisták szubjektív biztonságérzete ugyanis nem feltétlenül fedi egymást, ezért a turisták gyakran az indokoltnál nagyobb vagy kisebb kockázatot tulajdonítanak az utazásnak (CUI et al. 2016). Ez egyben az is jelenti, hogy a magas kockázatú desztinációk nem feltétlenül riasztják el a turistákat (RITTICHAINUWAT CHAKRABORTY 2009).

Így jelen kutatás arra a kérdésre keresi a választ, hogy a konfliktusövezetekben található desztinációkban hogyan befolyásolja az észlelt kockázat az utazási szándékot. Pontosabban azt vizsgáljuk, hogy milyen változók erôsítik vagy gyengítik az észlelt kockázat és az utazási szándék közötti kapcsolatot. Az észlelt kockázat turisztikai látogatók magatartására gyakorolt hatásának elemzése és az indirekt hatások azonosítása több szempontból fontos. Egyrészt a kutatás hozzájárul annak 
megértéséhez, hogy az utazókat milyen tényezók befolyásolják a konfliktusövezetekben lévő desztinációk választásakor, másrészt azonosíthatóvá válnak azok az eszközök, amelyekkel a piaci szereplők csökkenthetik az észlelt kockázatot, illetve megakadályozhatják a turizmus csökkenését.

A tanulmány a következőképpen épül fel. Elsóként a konfliktusok és az észlelt kockázat turizmushoz kötődő szakirodalmát dolgozzuk fel, majd a tervezett magatartás elméletét tárgyaljuk, amely segítséget nyújt az észlelt kockázat és az utazási szándék kapcsolatának elemzésében magas kockázatú desztinációk esetén. A cikk végterméke egy elméleti keretmodell, amely képes elóre jelezni a konfliktusövezetekben található desztinációkba való utazás szándékát. A modellben az észlelt kockázat és bizonytalanság hatása a tényleges magatartás iránti attitúdön, a szubjektív normákon és az észlelt magatartásirányításon keresztül érvényesül az utazási szándékra vonatkozóan, amelyet a desztinációval kapcsolatos korábbi tapasztalat és a desztinációs imázs is befolyásol.

\section{Szakirodalmi áttekintés}

Ebben a fejezetben áttekintjük a kutatási kérdéshez kapcsolódó legfontosabb fogalmakat (konfliktus, észlelt kockázat), illetve az észlelt kockázathoz kötódően a tervezett magatartás elméletét és alkalmazását a turizmus-kutatásokban.

\subsection{A TURIZMUST BEFOLYÁSOLÓ KONFLIKTUSOK}

A turizmust is érintó konfliktusok nem új keletúek az egyébként népszerú desztinációkban. Ilyen esemény volt 1972-ben a müncheni olimpiai játékok idején történt terrortámadás, vagy 1997-ben a közvetlenül turistákat célzó egyiptomi terrorista akció (LEPP - GIBSON 2003). A 2001. szeptember 11-i terrorcselekmény szintén jelentős visszaesést jelentett a turizmusban (MARTON et al. 2018), amelyet számos népszerú desztináció (például Franciaország, Spanyolország, Egyesült Királyság, Belgium, Németország) megtapasztalt.

A 2011-tól kezdődő Arab Tavasz a Közel-Keleten további instabilitást és politikai konfliktusokat okozott, valamint jelentős negatív hatást gyakorolt a turizmusra a régióban (AVRAHAM 2015). A konfliktusok száma világszerte növekedett. 2016ban 402 konfliktust figyelt meg a Heidelberg Institut for International Conflict Research kutatóintézet (2017), amelyből 226 volt erőszakkal járó konfliktus, ahol gyakran a turisták voltak a támadások célpontjai.

A konfliktus a latin confligere szóból származik, jelentése értékekért, érdekekért folyó küzdelem, amely státuszt, hatalmat és erőforrásokat biztosít és célja, hogy a riválisokat semlegesítse, megsebesítse vagy megsemmisítse (FARMAKI 2017). A Heidelberg Institut for International Conflict Research kutatóintézet (2017) államok közötti, államon belüli, szubállami és transzállami konfliktusokat különböztet meg. Az államok közötti konfliktus nemzetközileg elismert, az államot képviseló szereplők között alakul ki. Az államon belüli konfliktus állami és nem állami szereplók között jön létre. A szubállami konfliktust nem az államot képviseló érdekcsoportok hozzák létre. A transzállami konfliktusok az államot képviseló és egyéb szereplők között jönnek létre és legalább két szuverén állam közötti politikai konfliktusból fakadnak. Bár a konfliktusokat számos kutató (CLEMENTS - GEORGIOU 1998, HALL 2010, RITCHIE 2004, SÖNMEZ 1998, ALVAREZ - CAMPO 2014) tanulmányozta, a kutatások inkább általános szinten vizsgálták azok hatásait. Bármely típusú konfliktusról legyen is szó, a turisták utazással összefüggó észlelt kockázatára nagy valószínúséggel hatást fog gyakorolni.

\subsection{AZ ÉSZLELT KOCKÁZAT SZEREPE AZ UTAZÁSI DÖNTÉSEKBEN}

BAUER (1960) elsóként foglalkozott a marketing-szakirodalomban a kockázat szerepével és megállapította, hogy a fogyasztók magatartása mindig kockázatcsökkentésre irányul és döntéseiket nem a valós, hanem az észlelt kockázat alapján hozzák meg. REISINGER és MAVONDO (2005) a kockázatot annak a valószínúségeként határozta meg, hogy sérülés, veszteség, veszély vagy valamilyen értékes dolog elvesztése következik be. A kockázat „olyan állapot, amelynek során számos potenciálisan bekövetkező esemény meghaladja azoknak az eseményeknek a számát, amelyek ténylegesen be fognak következni és valamilyen valószínúség társul hozzájuk" (REISINGER MAVONDO 2005:212). A bizonytalanságot az különbözteti meg a kockázattól, hogy nem kapcsolódik hozzá valószínúség, azaz egy olyan szituáció, amely során bármi megtörténhet. Ennek következtében a kockázat és bizonytalanság közötti különbség a potenciális veszteség, veszély bekövetkezésének valószínúségében van. Míg az emberek egy döntés következményét eltérő kockázatúnak észlelik, addig bizonytalanság esetén a várható veszteséghez nem rendelnek valószínúséget (BECKER - KNUDSEN 2005).

A turizmushoz kötődő kockázatészlelés a turisták értékelését tükrözi arról, hogy megítélésük szerint a turisztikai tevékenységek és folyamatok mennyire bizonytalanok (CUI et al. 2016). A koc- 
Lektorált tanulmányok

kázat szerepe a turizmuskutatásokban a 2001. szeptember 11-i terrortámadásokat követóen vált jelentős kutatási területté. A terrortámadás előtt a kutatók fizikai-eszközökkel kapcsolatos, vakáció-specifikus és desztináció-specifikus kockázatot különböztettek meg (ROEHL - FESENMAIER 1992), illetve pénzügyi, pszichológiai, elégedettségi és időbeli kockázatokat elemeztek (SÖNMEZ - GRAEFE 1998a). A terrortámadás után viszont felértékelődött a fizikai kockázat szerepe (MARTON et al. 2018). Ilyen fizikai kockázatot jelentenek a terrorizmussal, a háborúval, a politikai instabilitással, az egészségügyi problémákkal és a kriminalitással összefüggó kockázatok (LEPP GIBSON 2003)

QUINTAL és szerzôtársai (2010) a kockázat és a bizonytalanság eltérő hatását vizsgálták az utazással kapcsolatos döntési folyamatra vonatkozóan. Kutatásuk során arra jutottak, hogy az emberek a kockázatot és a bizonytalanságot konzisztensen érzékelik az azonos objektív kockázatot jelentő szituációkban, de a turisták nem egyformán kockázatvállalók.

YANG és NAIR (2014) az észlelt kockázat belső és külső befolyásoló tényezőit azonosította. A külső tényezők azokat az információforrásokat testesítik meg, amelyek tájékoztatják az utazót a tényleges kockázatokról, így például a hivatalos figyelmeztetések, sajtóhírek. Belső tényezőnek számítanak a turista demográfiai, pszichográfiai és kulturális jellemzői, amelyek azt befolyásolják, hogy a tényleges veszélyhez képest az utazó nagyobb vagy kisebb kockázatot észlel-e. A kockázattúrés például fontos szerepet játszik abban, hogy a turisták hogyan szervezik meg az útjukat és mekkora jelentóséget tulajdonítanak az egyes utazási kockázattípusoknak, milyen kockázatkezelési kompetenciákat alakítanak ki (WILLIAMS - BALÁ - 2013). A nagyobb kockázatot vállaló egyéneket kifejezetten vonzzák a magas kockázatú desztinációk (például Kenya, Palesztina) és a veszéllyel járó tevékenységek (például extrém sportok és hegymászás) (LEPP - GIBSON 2008). Hasonlóan növeli a kockázatvállalást az újdonságkereső magatartás (LEPP - GIBSON 2003), a szervezett utazásokat és a tömegturizmust elkerülő független turisták kevésbé tartanak a terrorizmustól vagy a politikai instabilitás okozta kockázatoktól. A fiatal hátizsákos turisták például az utazás során felmerülő kockázatokat inkább hozzáadott értéknek tekintik, ahol az észlelt kockázat növeli az utazási szándékot (RITTICHAINUWAT - CHAKRABORTY 2009). A kulturális különbségek is hatnak az észlelt kockázatra. REISINGER és MAVONDO (2005) kimutatta, hogy más országok turistáihoz képest a brit és kanadai turisták aggódtak a legkevésbé az utazási kockázatok miatt, ók érezték leginkább biztonságban magukat és és a legkevésbé tartottak a nemzetközi utazástól. Ezenkívül megállapították, hogy adott országon belül a szubkultúrák is hatással vannak a kockázatvállalásra. Az információkeresés szintén meghatározó az utazással kapcsolatos döntéshozatalban. A turisták számos forrásból gyújtenek információkat, hogy az utazással kapcsolatos észlelt kockázatukat csökkenteni tudják. Az észlelt kockázat és a különböző kockázattípusok pozitívan hatnak az információkeresési és döntéshozatali magatartásra (MASER - WEIERMAIR 1998).

$\mathrm{Az}$ észlelt kockázatot továbbá meghatározza az utazással kapcsolatos elózetes tapasztalat, amely vonatkozhat a nemzetközi utazásra általában, illetve egy konkrét desztinációra (SÖNMEZ - GRAEFE 1998b). A helyi kultúrát jól ismerő utazók nagyobb biztonságban érzik magukat, hisz az előzetes utazási tapasztalat növeli a biztonságérzetüket, így kevésbé hajlamosak kerülni a magas kockázatú régiókat. WONG és YEH (2009) szintén arra az eredményre jutott, hogy az utazással kapcsolatos ismeretek gyengítik az észlelt kockázat negatív hatását az utazási szándékra vonatkozóan. Magas észlelt kockázatú desztinációk esetében FUCHS és REICHEL (2011) a desztinációt első alkalommal felkeresó, illetve az azt újralátogató turisták közötti kapcsolatot hasonlította össze a kockázatészlelésre, a kockázatcsökkentő stratégiákra és a látogatás motivációjára vonatkozóan. Az eredmények arra világítottak rá, hogy azok, akik első alkalommal utaznak a desztinációba, ember által okozott kockázatot, szocio-pszichológiai kockázatot, ételkockázatot és idójárás-kockázatot érzékelnek. Azok, akik már többször felkeresték a desztinációt, pénzügyi kockázatot, szolgáltatásminőséggel, természeti katasztrófával, autóbalesettel kapcsolatos kockázatokat érzékelnek a desztinációval kapcsolatban. Ráadásul, az első alkalommal utazók relatíve nagyszámú kockázatcsökkentési stratégiát használnak, míg az újralátogatók a kockázatcsökkentő stratégiákat, beleértve az utazási költségek csökkentését is, saját tapasztalatokkal helyettesítik (FUCHS - REICHEL 2011).

HAJIBABA és szerzôtársai (2015) válságrezisztens turistákat vizsgáltak, akik nem vesznek tudomást a kockázatokról és nem dolgoznak ki kockázatkerülési stratégiákat. A kutatási eredmények alapján ezeknek az utasoknak az általános kockázati attitúdjük stabil maradt, a kockázatészlelés inkább a specifikus területekre irányult, ezért különböző magatartási kimenetekhez vezetett. Ez a jelenség azzal magyarázható, 
hogy például a terrorizmussal összefüggő észlelt kockázat negatív hatása nem érvényesül hosszú távon (RITTICHAINUWAT - CHAKRABORTY 2009). WOLFF és LARSEN (2014) arra a meglepó eredményre jutott, hogy a 2011. évi terrortámadás után Norvégiában csökkent az észlelt kockázat szintje a fokozottabb biztonsági intézkedések miatt.

\subsection{A TERVEZETT MAGATARTÁS ELMÉLETE}

Az egyik leggyakrabban használt, racionális választáson alapuló elméleti megközelítés a tervezett magatartás modellje, amely az egyének döntéshozatalát magyarázza meg (HAN 2015). A tervezett magatartás modelljét AJZEN (1991) az indokolt cselekvés elméletének (AJZEN - FISHBEIN 1980) továbbfejlesztéseként dolgozta ki. Az elmélet szerint a tényleges magatartást a cselekvési szándék elózi meg, amelyet a tényleges magatartás iránti attitúd, a döntéshozó szubjektív normái és az észlelt magatartásirányítás határoznak meg. A cselekvési szándék azokat a motivációs tényezóket fogja át, amelyek megmutatják, mennyi erőfeszítést hajlandóak az egyének tenni, hogy az adott magatartást megvalósítsák. A tényleges magatartás iránti attitûd a magatartás kedvezó vagy kedvezőtlen értékelésére utal. A szubjektív norma az egyén által észlelt társadalmi, közösségi nyomást tükrözi a tényleges magatartás megvalósításával kapcsolatban. Az észlelt magatartási kontroll az egyén megítélését tükrözi, hogy mennyire rendelkezik azokkal az erőforrásokkal, képességekkel, lehetőségekkel, amelyekkel meg tudja valósítani a tényleges magatartást (AJZEN 1991).

A tervezett magatartás elméletét számos tudományágban sikeresen tesztelték, így a turizmussal és vendéglátással foglalkozó kutatások is előszeretettel alkalmazzák (QUINTAL et al. 2010, YUZHANIN - FISHER 2016, HSIEH et al. 2016). A tervezett magatartás elméletét adaptálták az utazási módok kiválasztásához (BAMBERG et al. 2003, MADHA et al. 2016), a tajvani desztináció-választás modellezéséhez (LAM - HSU 2006, BIANCHI et al. 2017), a szállásválasztáshoz (HAN - KIM 2010, MAO - LYU 2017), (CHENG et al. 2006), a nemzetközi utazás iránti attitúd méréséhez (SPARKS - PAN 2009), a kulturális örökség felkeresésének a modellezéséhez (ALONSO et al. 2015), a gasztronómiai turizmussal kapcsolatos magatartás elemzéséhez (SU et al. 2016), továbbá a természeti kockázattal bíró desztinációk felkereséséhez (GSTAETTNER et al. 2017).

A tervezett magatartás elmélete annak köszönheti népszerúségét, hogy a modell számos lehetőséget kínál az újabb változókkal való bővítésre, ami növeli az előrejelzési képességét a viselkedési szándékra és a tényleges magatartásra vonatkozóan (HAN - KIM 2010).

LAM és HSU (2006) szerint például a magatartással kapcsolatos attitúd, a szubjektív normák és az észlelt magatartásirányítás mellett a korábbi magatartás is meghatározza a viselkedési szándékot. SU és szerzőtársai (2016) az éttermi turizmus kontextusában korábbi tapasztalatokkal, társadalmi-demográfiai jellemzókkel, valamint az éttermi turizmus iránti érdeklődéssel egészítették ki a tervezett magatartás modelljét. PHETVAROON (2006) a desztináció eredetét használta moderáló változóként, amely hatással volt a szubjektív normák és a viselkedési szándék kapcsolatára olyan desztinációk esetén, ahol a közel múltban valamilyen válság alakult ki.

\section{Elméleti keretmodell}

A tanulmány egy olyan elméleti keretmodell létrehozását túzte ki célul, amely az észlelt kockázat utazási szándékra gyakorolt hatását mutatja meg a konfliktusövezetekben található desztinációkban. A modell középpontjában a konfliktusövezetben található desztinációkba való utazási szándék áll. Az utazási szándék kifejezi, hogy az utazó mennyi erófeszítést hajlandó tenni az utazás megvalósításának érdekében (QUINTAL et al. 2010). Az utazási szándék az utazás iránti attitûd, a szubjektív normák és az utazás fölött észlelt kontroll függvénye (AJZEN 1991).

Az utazással kapcsolatos attitúdök olyan tanulás és tapasztalat révén kialakult beállítódások, amelyek konzisztens reakciót váltanak ki a fogyasztóból egy adott dologgal kapcsolatban (LAM - HSU 2006). A turizmusban a desztinációk iránt pozitív vagy negatív attitúd alakul ki, amely az észlelt desztinációjellemzők egyéni értékelésén alapul (MOUTINHO 1987). A konfliktusövezetek iránti attitúd gyakran negatív a magasabb észlelt kockázat miatt.

Az utazási szándékot befolyásolják a szubjektív normák, amelyek az egyénre gyakorolt társadalmi nyomást jelenítik meg. A szubjektív normákat fóként az egyén referenciacsoportjai formálják, amelyek az egyén meggyőződésére, attitúdjére és döntéseire gyakorolnak hatást (MOUTINHO 1987). A szubjektív normákat két fontos tényező alakítja. Egyrészt az egyén meggyőződése, hogy a számára legfontosabb személyek mit gondolnak arról, hogy mit kellene tennie, másrészt az egyéni motiváció erôssége, amely szabályozza a referenciacsoporthoz való 
Lektorált tanulmányok

alkalmazkodás mértékét (AJZEN - FISHBEIN 1980). Konfliktusövezetben található desztinációkkal kapcsolatban a referenciacsoportok (például család, barátok) kevésbé támogathatják az utazási szándékot, ezért csökkenhet az utazás iránti motiváció.

Az utazási szándékot az is meghatározza, hogy az utazás fölött észlelt kontroll mennyire erôs, azaz az egyén mennyire érzékeli nehéznek vagy könnyúnek a magatartás megvalósítását (AJZEN 1991). Az utazás megvalósításával kapcsolatos magabiztosság ugyanis függ az utazó által elérhető erőforrásoktól (AJZEN 1991, QUINTAL et al. 2010). A konfliktusövezetekben található desztinációk esetén az utazással kapcsolatos észlelt kontroll különösen fontos szerepet játszik, mivel a magasabb kockázat több előkészületet és több anyagi erőforrást igényelhet.

$\mathrm{Az}$ egyén által észlelt társadalmi elvárások, azaz a szubjektív normák hatással lehetnek a tényleges magatartás iránti attitúdre és az észlelt magatartásirányításra is. Az emberek ugyanis hajlamosak figyelembe venni mások várakozásait a saját attitúdjük kialakítása során (OLIVER - BEARDEN 1985). A konfliktusövezetek negatív társadalmi megítélése kedvezőtlen attitúdöket alakíthat ki az utazóban. A szubjektív normák észlelt magatartásirányításra gyakorolt hatása azzal magyarázható, hogy a tényleges magatartás kedvezótlen társadalmi megítélése csökkentheti az észlelt kontrollt a magatartás fölött. Különösen érvényes lehet ez az összefüggés konfliktusövezeti desztinációk esetén, mivel a negatív szubjektív normák hatására az utazó úgy érezheti, hogy a cselekvési képessége ezekben a desztinációkban akadályokba ütközhet (QUINTAL et al. 2010).

A magatartás iránti attitûd, a szubjektív normák és a magatartás fölött észlelt kontroll azonban nagymértékben függ attól, hogy az utazó milyen mértékú kockázatot és bizonytalanságot észlel az utazással kapcsolatban. Az utazási szándékot modellező kutatások (QUINTAL et al. 2010, HSIEH et al. 2016, MAO - LYU 2017, CHEN - PENG 2018) alapján mind az észlelt kockázat, mind az észlelt bizonytalanság befolyásolhatja az utazással kapcsolatos attitúdöt. Az utazással összefüggésben észlelt kockázatok növekedése kedvezôtlen irányban változtatja meg az utazás iránti attitúdöt a konfliktusövezetekben található desztinációk esetén. Az észlelt bizonytalanság továbbá negatív hatással van az észlelt magatartásirányításra (QUINTAL et al. 2010, WILLIAMS - BALÁŽ 2014), mert bizonytalan kimenetelú eseményeknél az egyén korlátozottabban tudja kontrollálni a magatartását. Olyan úti céloknál, amelyek konfliktusövezetekben ta- lálhatóak, az észlelt bizonytalanság magas lehet, amelynek következtében a turista észlelheti úgy, hogy a bizonytalan kimenettel járó magatartás irányítása akadályokba ütközhet.

Figyelembe véve, hogy egy adott kockázatot nagyon különbözőképpen észlelhetnek az utasok, célszerú meghatározni azokat a pszichográfiai (kockázatvállaló képesség, újdonságkeresés) és kulturális jellemzőket, amelyek a kockázatészlelésben tapasztalható egyéni különbségeket létrehozzák. Az egyéni kockázatvállalási hajlandóság mértéke befolyásolja, hogy az egyén mekkora jelentőséget tulajdonít az egyes utazási kockázatoknak (WILLIAMS - BALÁŽ 2013). Minél magasabb kockázatot hajlandó vállalni az utazó, annál kisebb lesz az észlelt kockázat és bizonytalanság a konfliktusövezetben található desztinációk esetében. Az újdonságkereső magatartás szintén csökkenti az észlelt kockázatot és bizonytalanságot (LEPP - GIBSON 2003). Az új, akár veszélyekkel járó utazást az újdonságkeresók az utazás hozzáadott értékeként kezelik. Így a konfliktusövezetekkel kapcsolatos magasabb észlelt kockázat növeli az utazás iránti pozitív attitúdöt és ezen keresztül az utazási szándékot. A kulturális különbségek is hatnak az észlelt kockázatra (REISINGER - MAVONDO 2005). Azokban a kultúrákban, amelyek érzékenyebbek a bizonytalanságra, az egyének az utazás során igyekeznek kerülni a kockázatot és a potenciálisan veszélyt jelentó helyzeteket (HOFSTEDE 2001).

Számos kutatás (PHETVAROON 2006, HAN - KIM 2010, YE et al. 2017, SU et al. 2016) feltételezi továbbá, hogy a desztinációval kapcsolatos korábbi tapasztalat szintén hatással van az utazási szándékra. A konfliktusövezetben lévő desztinációkkal kapcsolatos korábbi tapasztalat növeli az utazási szándékot. Nem csupán a korábbi tapasztalat, hanem a desztinációról kialakult imázs is hatással lehet az utazási szándékra. A fogyasztók ugyanis nagymértékben támaszkodnak a desztinációk imázsára, amikor az úti cél kiválasztásáról döntenek (UM - CROMPTON 1990). A desztinációs imázs a desztinációval kapcsolatos kognitív és affektív értékelések összessége (MacKAY - FESENMAIER 1997, BALOGLU MANGALOGLU 2001, HOSANY et al. 2006). A desztinációs imázs a kutatások szerint befolyásolja a desztináció kiválasztását (LEPP et al. 2011, MOSSBERG - KLEPPE 2005), miszerint a turisták vonzónak találják és nagyobb utazási szándékot mutatnak a pozitív imázzsal rendelkező desztinációkkal szemben még abban az esetben is, ha magát az országot nem ítélik meg pozitívan.

Az elméleti keretmodellt az 1. ábra mutatja be. 
Elméleti keretmodell: az észlelt kockázat és bizonytalanság hatása az utazási szándékra, konfliktusövezetekben található desztinációk esetén

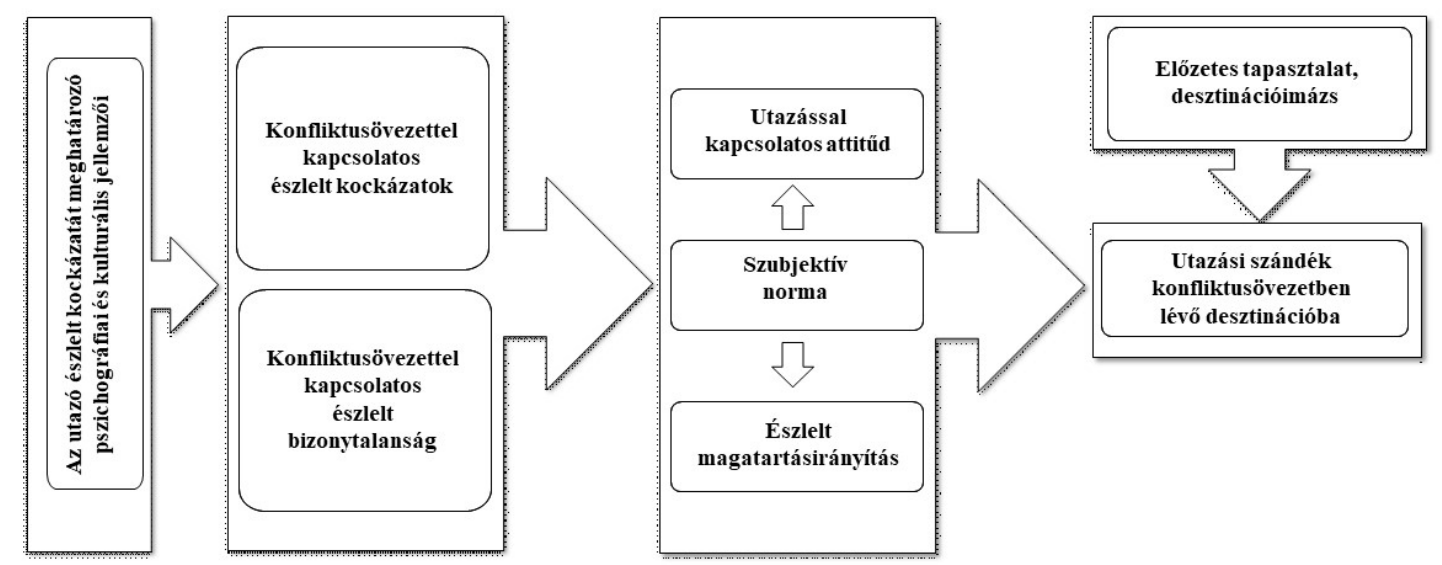

Forrás: saját szerkesztés

\section{4. Összefoglalás}

A tanulmány célja, hogy egy olyan elméleti keretmodellt alakítson ki, amely az észlelt kockázat és a turisták látogatási szándékának összefüggését vizsgálja a konfliktusövezetekben található desztinációkban.

A modell egyik újdonságértéke, hogy meghatározza azokat a tényezóket, amelyek befolyásolják az utazási szándékot a konfliktusövezetekben található, magas kockázatú desztinációk esetén. Bár több modellben (például QUINTAL et al. 2010, HSIEH et al. 2016) szerepel az észlelt kockázat és észlelt bizonytalanság, azonban az általunk létrehozott elméleti keret azokat az egyéni tényezóket is figyelembe veszi, amelyek az eltérő kockázatészlelésért felelősek. Így például a kockázatvállalás, az újdonságkeresés, vagy a kulturális tényezók határozzák meg azt, hogy az egyes utazók milyen mértékú kockázatot tulajdonítanak ugyanannak a desztinációnak. A nagyobb kockázatot vállaló, újdonságok, kalandok iránt nyitott turisták alacsonyabb kockázatot fognak érzékelni egy konfliktusövezetben található desztináció esetén. Ennek következtében az utazás iránti attitúdjük pozitívabb, alacsonyabb a rájuk nehezedő társadalmi nyomás és nagyobb kontrollt érzékelnek a magas kockázatú desztinációba való utazás fölött, ami magasabb utazási szándékban fog megnyilvánulni.

A másik fontos hozzáadott értéke a modellnek, hogy az utazási szándékot nemcsak az utazás iránti attitúd, a szubjektív normák és az utazással kapcsolatos észlelt kontroll befolyásolja, hanem a desztinációval kapcsolatos korábbi tapasztalatok és a desztinációimázs is. Az előző kutatásokban 
is pozitívan hat. Mindezek hatására növekedhet az utazási szándék a konfliktusövezetekben található desztinációkban.

Jelen cikknek nem volt célja, hogy empirikus módon tesztelje a modellt. A jövőbeni kutatások során az elméleti keretmodellt terveink szerint analitikus modellé alakítjuk át, amely magában foglalja a modell elemeinek operacionalizálását, az egyes elemek közötti összefüggések hipotézisként való megfogalmazását. A hipotéziseket kvantitatív kutatás keretében statisztikai módszerekkel teszteljük.

\section{Felhasznált irodalom}

AJZEN, I. - FISHBEIN, M. (1980): Understanding attitudes and predicting social behavior. New Jersey: Prentice-Hall.

AJZEN, I. (1991): The theory of planned behavior. Organizational Behavior and Human Decision Processes. 50(2). pp. 179-211.

ALONSO, A. D. - SAKELLARIOS, N. PRITCHARD, M. (2015): The theory of planned behaviour in the context of cultural heritage tourism. Journal of Heritage Tourism. 10(4). pp. 399-416.

ALVAREZ, M. D. - CAMPO, S. (2014): The influence of political conflicts on country image and intention to visit: A study of Israel's image. Tourism Management. 40. pp. 70-78.

AVRAHAM, E. (2015): Destination image repair during crisis: Attracting tourism during the Arab Spring uprisings. Tourism Management. 47. pp. 224-232.

BALOGLU, S. - MANGALOGLU, M. (2001): Tourism destination images of Turkey, Egypt, Greece, and Italy as perceived by US-based tour operators and travel agents. Tourism Management. 22(1). pp. 1-9.

BAMBERG, S. - AJZEN, I. - SCHMIDT, P. (2003): Choice of travel mode in the theory of planned behavior: The roles of past behavior, habit, and reasoned action. Basic and Applied Social Psychology. 25(3). pp. 175-187.

BAUER, R. A. (1960): Consumer behavior as risk-taking. In: Hancock, R. S. (ed.): Dynamic marketing for a changing world. Proceedings of the 43rd. Conference of the American Marketing Association. pp. 389-398.

BECKER, M. - KNUDSEN, T. (2005): The role of routines in reducing pervasive uncertainty. Journal of Business Research. 58(6). pp. 746-757.

BIANCHI, C. - MILBERG, S. - CÚNEO, A. (2017): Understanding travellers' intentions to visit a short versus long-haul emerging vacation destination: The case of Chile. Tourism Management. 59. pp. 312-324.
CHEN, A. - PENG, N. (2018): Examining consumers' intentions to dine at luxury restaurants while traveling. International Journal of Hospitality Management. 71. pp. 59-67.

CHENG, S. - LAM, T. - HSU, C. (2006): Negative Word-of-Mouth Communication Intention: An Application of the Theory of Planned Behavior. Journal of Hospitality and Tourism Research. 30(1). pp. 95-116.

CHEW, E. Y. T. - JAHARI, S. A. (2014): Destination image as a mediator between perceived risks and revisit intention: A case of post-disaster Japan. Tourism Management. 40. pp. 382-393.

CLEMENTS, M. - GEORGIOU, A. (1998): The impact of political instability on a fragile tourism product. Tourism Management. 19(3). pp. 283-288.

CUI, F. - LIU, Y. - CHANG, Y. - DUAN, J. - LI, J. (2016): An overview of tourism risk perception. Natural Hazards. 82(1). pp. 643-658.

FARMAKI, A. (2017): The tourism and peace nexus. Tourism Management. 59. pp. 528-540.

FUCHS, G. - REICHEL, A. (2011): An exploratory inquiry into destination risk perceptions and risk reduction strategies of first time vs. repeat visitors to a highly volatile destination. Tourism Management. 32(2). pp. 266-276.

GSTAETTNER, A. M. - RODGER, K. - LEE, D. (2017): Visitor perspectives of risk management in a natural tourism setting: An application of the Theory of Planned Behaviour. Journal of Outdoor Recreation and Tourism. 19. pp. 1-10.

HAJIBABA, H. - GRETZEL, U. - LEISCH, F. DOLNICAR, S. (2015): Crisis-resistant tourists. Annals of Tourism Research. 53. pp. 46-60.

HALL, C. M. (2010): Crisis events in tourism: Subjects of crisis in tourism. Current Issues in Tourism. 13(5). pp. 401-417.

HAN, H. (2015): Travelers pro-environmental behavior in a green lodging context: Converging value-belief-norm theory and the theory of planned behavior. Tourism Management. 47. pp. 164-177.

HAN, H. - KIM, Y. (2010): An investigation of green hotel customers' decision formation: Developing an extended model of the theory of planned behavior. International Journal of Hospitality Management. 29(4). pp. 659-668.

HOFSTEDE, G. (2001): Culture's Consequences: Comparing Values, Behaviors, Institutions, and Organizations across Nations. Sage Publications.

HOSANY, S. - EKINCI, Y. - UYSAL, M. (2006): Destination image and destination personality: An application of branding theories to tourism places. Journal of Business Research. 59(5). pp. 638-642. 
HSIEH, C. - PARK, S. H. - McNALLY, R. (2016): Application of the extended theory of planned behavior to intention to travel to Japan among Taiwanese youth: Investigating the moderating effect of past visit experience. Journal of Travel $\mathcal{E}$ Tourism Marketing. 33(5). pp. 717-729.

LAM, T. - HSU, C. H. C. (2006): Predicting behavioral intention of choosing a travel destination. Tourism Management. 27(4). pp. 589-599.

LARSEN, S. - BRUN, W. - OGAARD, T. (2007): Tourists' worries. In: McDonnell, I. Grabowski, S. - March, R. (eds): CAUTHE 2007: Tourism - Past Achievements, Future Challenges. Conference Paper. University of Technology, Sydney. pp. 1203-1214.

LEPP, A. - GIBSON, H. - LANE, C. (2011): Image and perceived risk: A study of Uganda and its official tourism website. Tourism Management. 32(3). pp. 675-684.

LEPP, A. - GIBSON, H. (2003): Tourist roles, perceived risk and international tourism. Annals of Tourism Research. 30(3). pp. 606-624.

LEPP, A. - GIBSON, H. (2008): Sensation seeking and tourism: Tourist role, perception of risk and destination choice. Tourism Management. 29(4). pp. 740-750.

MacKAY, K. J. - FESENMAIER, D. R. (1997): Pictorial element of destination in image formation. Annals of Tourism Research. 24(3). pp. 537-565.

MADHA, A. - SALMAN, A. D. - HUSSAIN, H. D. - BORHAN, N. - RIZA ATIQ, O. K. R. (2016): Analysis of travel behaviour in Petaling Jaya, Malaysia: an application of the theory of planned behaviour. Archives of Transport. 38(2). pp. 29-38.

MAO, Z. - LYU, J. (2017): Why travellers use Airbnb again? An integrative approach to understanding travellers' repurchase intention. International Journal of Contemporary Hospitality Management. 29(9). pp. 2464-2482.

MARTON ZS. - BIRKNER Z. - KELLER K. BERKESNÉR.N.(2018):Aturizmusbiztonságban rejlő marketing és menedzsment implikációk. Turizmus Bulletin. 18(2). pp. 12-20.

MASER, B. - WEIERMAIR, K. (1998): Travel decision-making: from the vantage point of perceived risk and information preferences. Journal of Travel and Tourism Marketing. 7(4). pp. 107-121.

MICHALKÓ G. (2012): Turizmológia. Akadémiai Kiadó, Budapest.

MOSSBERG, L. - KLEPPE, I. A. (2005): Country and destination image - different or similar image concepts? The Service Industries Journal. 25(4). pp. 493-503.
MOUTINHO, L. (1987): Consumer behaviour in tourism. European Journal of Marketing. 21(10). pp. $5-44$

OLIVER, R. - BEARDEN, W. (1985): Crossover effects in the theory of reasoned action: a moderating influence attempt. The Journal of Consumer Research. 12(3). pp. 324-340.

PHETVAROON, K. (2006): Application of the theory of planned behavior to select a destination after a crisis: A case study of Phuket, Thailand. PhD Thesis. Oklahoma State University.

QUINTAL, V. A. - LEE, J. A. - SOUTAR, G. N. (2010): Risk, uncertainty and the theory of planned behavior: A tourism example. Tourism Management. 31. pp. 797-805.

REISINGER, Y. - MAVONDO, F. (2005): Travel anxiety and intentions to travel internationally: implications of travel risk perception. Journal of Travel Research. 43(3). pp. 212-225.

RITCHIE, B. W. (2004): Chaos, crises and disasters: A strategic approach to crisis management in the tourism industry. Tourism Management. 25(6). pp. 669-683.

RITTICHAINUWAT, B. N. - CHAKRABORTY, G. (2009): Perceived travel risks regarding terrorism and disease: The case of Thailand. Tourism Management. 30(3). pp. 410-418.

ROEHL, W. S. - FESENMAIER, D. R. (1992): Risk perceptions and pleasure travel: An exploratory analysis. Journal of Travel Research. 30(4). pp. 1726.

SÖNMEZ, S. F. - GRAEFE, A. R. (1998a): Determining future travel behavior from past travel experience and perceptions of risk and safety. Journal of Travel Research. 37(2). pp. 171177.

SÖNMEZ, S. F. - GRAEFE, A. R. (1998b): Influence of terrorism risk on foreign tourism decisions. Annals of Tourism Research. 25(1). pp. 112-144.

SÖNMEZ, S. F. (1998): Tourism, terrorism, and political instability. Annals of Tourism Research. 25(2). pp. 416-456.

SPARKS, B. - PAN, G. W. (2009): Chinese Outbound tourists: Understanding their attitudes, constraints and use of information sources. Tourism Management. 30(4). pp. 483-494.

SU, D. N. - JOHNSON, L. - O'MAHONY, B. (2016): Tourists' intention to visit food tourism destination: A conceptual framework. In: Radzi, S. M. et al. (eds): Heritage, Culture and Society: Research agenda and best practices in the hospitality and tourism industry. pp. 267-272.

UM, S. - CHON, K. - RO, Y. (2006): Antecedents of revisit intention. Annals of Tourism Research. 33(4). pp. 1141-1158. 
UM, S. - CROMPTON, J. L. (1990): Attitude determinants in tourism destination choice. Annals of Tourism Research. 17(3). pp. 432-448.

WILLIAMS, A. M. - BALÁŽ, V. (2013): Tourism, risk tolerance and competences: Travel organization and tourism hazards. Tourism Management. 35. pp. 209-221.

WILLIAMS, A. M. - BALÁŽ, V. (2014): Tourism risk and uncertainty. Journal of Travel Research. 54(3). pp. 271-287.

WOLFF, K. - LARSEN, S. (2014): Can terrorism make us feel safer? Risk perceptions and worries before and after the July 22nd attacks. Annals of Tourism Research. 44. pp. 200-209.

WONG, J. - YEH, C. (2009): Tourist hesitation in destination decision making. Annals of Tourism Research. 36(1). pp. 6-23.

YANG, C. L. - NAIR, V. (2014): Risk perception study in tourism: Are we really measuring perceived risk? Procedia-Social and Behavioral Sciences. 144. pp. 322-327.

YE, B. H. - ZHANG, H. Q. - YUAN, J. (2014): Intentions to participate in wine tourism in an emerging market: Theorization and implications. Journal of Hospitality $\mathcal{E}$ Tourism Research. 41(8). pp. 1007-1031.

YUZHANIN, S. - FISHER, D. (2016): The efficacy of the theory of planned behavior for predicting intentions to choose a travel destination: a review. Tourism Review. 71(2). pp. 135-147.

\section{Internetes források}

Heidelberg Institut for International Conflict Research (2017): Conflict Barometer 2016. http://hiik.de/de/konfliktbarometer/pdf/ ConflictBarometer_2016.pdf, Letöltve: 2017. augusztus 6.

UNWTO (2016): UNWTO Annual Report 2015. http://cf.cdn.unwto.org/sites/all/files/pdf/ annual_report_2015_lr.pdf, Letöltve: 2017. május 6.

WTTC (World Travel and Tourism Council) (2017): World tourism indicators. https://tool.wttc.org/, Letöltve: 2017. május 6. 